\title{
The Factors Affecting the Trustworthiness of Customers towards the Usage of Internet Banking in Malaysia
}

\author{
Uma Murthy $^{1}$, Paul Anthony Mariadas ${ }^{1} \&$ Gopal Perumal ${ }^{1}$ \\ ${ }^{1}$ Global Leadership Research Unit, Faculty of Business, Accountancy and Management, SEGi University, \\ Malaysia
}

Correspondence: Uma Murthy, Global Leadership Research Unit, Faculty of Business, Accountancy and Management, SEGi University, Malaysia. Email: umamurthy@segi.edu.my

Received: February 10, 2017

Accepted: April 22, $2017 \quad$ Online Published: May 11, 2017

doi:10.5539/ijbm.v12n6p1

URL: https://doi.org/10.5539/ijbm.v12n6p1

\begin{abstract}
The number of internet users in Malaysia is significantly high in comparison with other countries. It is reported that the number of internet users who were born in the year 2000 and above is almost near $70 \%$ in Malaysia. In 2015, the Malaysian internet users has exceeded to more than 19 million users. Therefore, the amount of banks that are implementing internet services to their customer is to be roughly 30 . Meanwhile, there are only 13 banks in Malaysia that offers mobile banking services to its customers. Although there has been a rapid distribution of mobile internet by banks, internet banking services is still not fully adopted by banks. The objective of the study is to study about the factor affecting the trustworthiness of customers towards the usage of internet banking in Malaysia. This research is about the trustworthiness of customers towards the usage of internet banking. There are a few variables of factors that affect the trustworthiness of customers towards the usage of internet banking and it is clearly explained and elaborated. The factors are competency, security, integrity performance and shared values. Next, the methodology quantitative approach has used in this research whereby 200 respondents were sampled by the population from using the simple random taking. Employed the SPSS Version 22.0, the multiple regression analysis and correlation analysis was created out to test the four hypothesis for this research. Moreover, this research will be conducted in Kota Damansara, Malaysia.
\end{abstract}

Keywords: Internet Banking, competency, security, integrity performance and shared values and trustworthiness

\section{Introduction}

Many banks have valued the importance of internet banking to improve their overall efficiency and to increase their profitability in the market. The banks have adopted resources for internet banking to support quicker transfer to reach their customers (Daniel, 1999). The evolution of internet banking changed the nature of personal customer-banker relationships and has open up the network channels to perform many banking services that used to be carried out over the counter (Giannakoudi, 1999). The usage of technology of banking began in the early 1970's with the introduction of the Automatic Teller Machine (ATM), credit cards and also telephone banking (Pang, 1995).

Internet banking has been developed throughout other nations improvising to the vast alteration of traditional banking (Alagheband, 2006). High rivalry amongst banks and technology improvements push banks to provide various types of services to a networking platform that can also be referred as internet banking. In the current communication level between humans that are lacking, internet banking is regarded as an opportunity for banks to strengthen the quality awareness of customers. The revolution of internet banking has reconstruct banks and financial institutions business strategy in order to increase and maintain competition in the market. Due to that, consumer today has developed high behavioral demands of expecting improvement in the flexibility and compatibility rather than traditional banking services.

The significance relationship between trust and internet banking had been proved by many studies. Trust happens when a certain party has the confidence to accept or to exchange others' reliability and honesty (Morgan \& Hunt, 1994). For example, trust is important in online purchasing, loyalties of a website, internet banking, and to gain specific information from a website (Chen, Gillenson \& Sherell, 2002). Trust is a necessary component when it comes to the uncertainty of an individual. If there is no uncertainty, customer will be reluctant to use the 
internet banking services (Kassim \& Abdulla, 2006). Purpose of this study is to find out the factors affecting the trustworthiness of customers towards the usage of Internet Banking in Malaysia.

This research is showed by the subsequent questions; (1) what is the relationship between competency and the trustworthiness of customer's towards the usage of Internet Banking in Malaysian context? (2) what is the relationship between security and the trustworthiness of customer's towards the usage of Internet Banking in Malaysian context? (3) what is the relationship between integrity performance and the trustworthiness of customer's towards the usage of Internet Banking in Malaysian context? and (4) what is the relationship between shared values and the trustworthiness of customer's towards the usage of Internet Banking in Malaysian context?

To seek the answers to these questions, this research will be organized into five (5) sections. Section one captures the introduction, section two discusses review of updated literatures, section three (3) highlights the methodology employed in analyzing empirical data for this research, section four (4) discusses data collection and analysis whilst, section five (5) provides the conclusion and recommendations, as well as the contributions and limitations of the research.

\section{Literature Review}

\subsection{The Definition of Trustworthiness of Customer towards the Usage of Internet Banking}

The dependent variable of this study is the trustworthiness of customers towards the usage of internet banking. Internet banking can be defined as the progression of the traditional way of banking into a new way of banking that customers obtain from accessing through an internet platform and communication channels (Yiu, Grant, \& Degar, 2007). Internet banking is also known as e-banking and online banking. Internet banking is the establishment of the website that can be viewed by customers as a service from banks and financial institutions (Sathye, 1999).

Internet banking can be defined in different type of ways. This is because different authors have different perspective towards the functions of internet banking. Internet banking could also be known as online banking and e-banking. Internet banking is the process whereby its services are delivered in a specific internet platform through networking (Yiu, Grant, \& Degar, 2007). In a basic understanding, internet banking can also be known as the development of webpage improvement by financial institution to provide information about its services (Daniel, 1999). Sathye (1999) mentioned that banks have totally adapted with the current technology phase changing its core of their services, delivery and consumption methods (Sathye, 1999).

In the today's world, technology has developed more competition for bank providers. Due to the rapid growth, many nations have transformed the practice of traditional banking. To reach customers globally and to eliminate the geographical limitations, banks have utilized the internet as a platform to deliver its services (Bradley and Stewart, 2003). According to Paynter and Lim (2001), electronic banking was first introduced in Malaysia in the year 1981. After a few years, the first electronic machine was introduced by banks to consumers which are the Automated Teller Machine (ATM). The convenience of an ATM machine provides consumers with an easier way to obtain banks' services (Paynter \& Lim, 2001).

In the year 2000, the Central Bank of Malaysia has permitted local banks to provide internet bank services to consumers. This offer was initiated by few banks such as Maybank and CIMB bank. Local banks offered services such as credit card payment, banking enquiries, transfers to third party and also account information. Mobile banking is also then implemented and has the same characteristics as internet banking. This is because mobile banking also uses the same platform as the computer in using the internet network. From the consumers' understanding, internet banking is a convenient and easy way in order to access one's finance account anywhere and anytime throughout the day. However, from the banks' understanding, internet banking is a strategy that was adopted to gain competitive advantage by offering various opportunities to customers.

\subsection{Competency}

Competency is defined as the ability of a certain service provider to offer desirable performance in order to fulfill customer needs and wants (Pay, Balaji, \& Kok, 2014). The advantages of competency include level of quality, consumer benefits and satisfaction (Rogers, 2010).

Good intentions are not always sufficient for a person to fulfil their expectation on a certain new implementation (Minhas \& Jacobs, 1996). Therefore competency is further explained as one of the factors that could generate trust from a person. Competence is defined as the ability of a certain service provider to offer desirable performance in order to fulfil customer needs and wants (Pay, Balaji, \& Kok, 2014). Rogers (2010), states that organizations which have tasks rely on competency because it can create the ability to reach goals (Rogers, 2010). 
In an internet banking perspective, competence is a certain belief about banks offers expertise in providing proper technological safety for internet banking users from financial frauds and the violation of privacy (Pay, Balaji, \& Kok, 2014). Pay et al. (2014) also states that in a high risk environment, it is important for the service provider to express strongly that they are capable to deliver what they have promised. Furthermore, competence from organization can also reduce the customers' perception towards risk and eventually increase the confidence towards internet banking (Pay, Balaji, \& Kok, 2014).

Customers may need certain reason the acquire reasons such as competency for customers to try new innovations. Through the usage of internet banking, it allows customers to make admission to their banking accounts without having the effects of time and place. Customers will be able to check their account or make any transactions anytime or anywhere. Furthermore, customers are able to access their banking accounts as it is easier to access it if internet banking is used (Tan \& Teo, 2000). Consumers will have the courage to adopt new innovations if they had identified the advantages and values of the innovation and may tend to leave the traditional way. Thus, the higher the competency in the innovation, the higher the rate of the new innovation will be adopted (Puschel \& Mazzon, 2010). In addition, Rogers (2010) stated that there is positive relationship between competency and the trustworthiness of customers towards the usage of internet banking (Rogers, 2010).

\subsection{Security}

Security is one of the most challenging factors for a certain firm or organization. The level of security can measure the level of harm that customers may fear. Risk could interfere with security from obtaining freedom. Security matters before any customer could trust the service provider (Nasri, 2011).

Aldridge et al. (1997) describes security as the most challenging factor for a company to go online. This is explained when a user uploads anything online, anyone from around the world can have access to the information (Aldridge, White, \& Forcht, 1997). Most of the important issues between customers and internet banking are the customer's trust of security when it comes to online banking transactions (Nilsson, Adams, \& Herd, 2005). When it comes to putting up your personal details and information on the network, everyone would feel that it is best to keep it private. This is because security has been identified as one of the most important factors that affect trust levels (Lee, 2002). Hutchinson et al. (2003) states that the worldwide web on the network is no longer invisible to anyone across the globe because in spite the security methods that are already available, there will always be a the concerns of the internet to be a medium of online transactions (Hutchinson and Warren, 2003).

Hajli and Lin (2014) also states that one of the main factors of the trustworthiness of internet banking is security, which is the most influential factor (Hajli \& Lin, 2014). Security issues will still be important although the development of IT had sanctioned banks to have a better secured platform (White \& Nteli, 2004). In other research, Adler and Kwon (2002) customers' awareness are also important in internet banking. This is because new technologies can facilitate more secured internet banking environment (Adler \& Kwon, 2002).

Security factor is vital towards the trustworthiness of customers towards the usage of internet banking. This is due to the risk that customers will face when conducting transactions online. Thus, security has a positive relationship with customers trust in the usage on internet banking (Cunningham, 2003). Sabagh and Molla (2004) conducted a research in Oman and they stated that they had identified the two main variables of internet banking which is trust and also security (Sabagh \& Molla, 2004). Therefore, if quality security is improved such as the existence of privacy protection seal when conducting a transaction online will develop more trust to customers (Rifon, LaRose, \& Choi, 2005). Finally, a research had been conducted and had stated that there is a noticeable positive relationship between security and the trustworthiness of internet banking (Hernandez and Mazzon, 2007).

\subsection{Integrity Performance}

Integrity performance can be defined as the service providers' quality in maintaining the demands from customers. The reputation of the service provider may be at stake if it does not convey a well performed quality by reaching the needs of the customers. If the service provider clarifies information or transactions smoothly could build more trust for maintaining and gaining customers (Ting, Kuen, Xien, Ying, \& Yew, 2013).

Integrity conveys an image of objectivity that contributes to the development of better reputation for the service provider. In an internet banking perspective, confidentiality influence better trust towards their customers (Pay, Balaji, \& Kok, 2014). Yap (2010) states that the smooth clarity in instructions given will improve customer confidence and their trust in internet banking. 
A report by Forrester Consulting states the studies on customer expectation on website performance are $75 \%$ and $99 \%$ out of it expects availability and performance from financial services. It also adds that the expectation from customer over performance comes second after security. More than half of the internet banking users expects the site to load lesser than 2 seconds. If it takes more, they would not dare to continue with the transactions (Crosman, 2010). With the growth of technology, banks would have to increase their way of retailing especially through online to keep up with the pace as well as be up to date to what their customers demand. Looking at the full overview, the evolution of internet banking has evolved and the performance is always getting better.

Customers' demands and acceptance is the main key for determining the practicality and success on implementing technology based on internet banking. Internet banking is said to be the sixth application that is most demand by customers. However there are certain transactions that customer prefer to go to the ATM or banks rather than using the internet platform (Sayar \& Wolfe, 2007). For business, managers would need to associate with the usage of internet banking as it is to improve performance efficiently in their business. Managers would consider on how efficient are the online banking performances that are provided by banks in order to make fast decisions. Therefore, evaluating on the performances of internet banking are very crucial by all its customers and it is an interest matter on how performance does relate with its users that researches are interested in researching on $(\mathrm{Wu}, 2010)$. Therefore, there are a genuinely positive relationship between integrity performance and the trustworthiness of customers towards the usage of internet banking.

\subsection{Shared Values}

Shared values can be defined when a customer has the knowledge of the goals set by the service provider (Mukherjee \& Nath, Role of electronic trust in online retailing: a re-examination of the commitment-trust theory, 2007). When customer has the same values as the service provider, trust may build in order to have a positive relationship with the trustworthiness of internet banking (Pay, Balaji, \& Kok, 2014).

In the past research, shared values also refer to customer perceive internet banking as the same for them in terms of goals and behaviour. This factor can simplify the communication or collaboration between customers and banks thereby could lead to mutual trust (Pay, Balaji, \& Kok, 2014). Mukherjee et al (2007) states that one of the most influential factors is shared values because it can develop trust in an online retail context. This means that shared values can determine the knowledge of fraud by customers, therefore trust in banks is improved (Mukherjee \& Nath, 2007). Customer perception towards the service providers' behaviours may lead to better satisfaction and also higher assurance. Thus, it could lead to better confidence then towards better trust.

There are a few important elements in shared values which one of it is ethics in banking. Ethics may determine whether or not banks are giving incomplete information, misconduct customers' confidential information or even sharing or selling customers information to other parties (Mukherjee \& Nath, 2003). With the aspects of good morality, honesty and ethics may increase trust (Huemer, 1998). Banks' ethics can enforce rules and regulations could build trust by explaining the security and privacy concerns to the customers.

In the past research, there are most surveys have found that there a consistent high levels of customers that are worried about privacy in online activities (Ackerman, Cranor, \& Reagle, 1999). Privacy violation is the main concern of internet banking, whereby they are concern on the misuse of confidentiality and lack of personal information saving. Most customers trust that internet can be intercepted and intervened by others (Yiu, Grant, \& Degar, 2007). Therefore, these factors have an obvious positive relationship between shared values and the trustworthiness of customers towards the usage of internet banking.

\section{Proposed Framework}

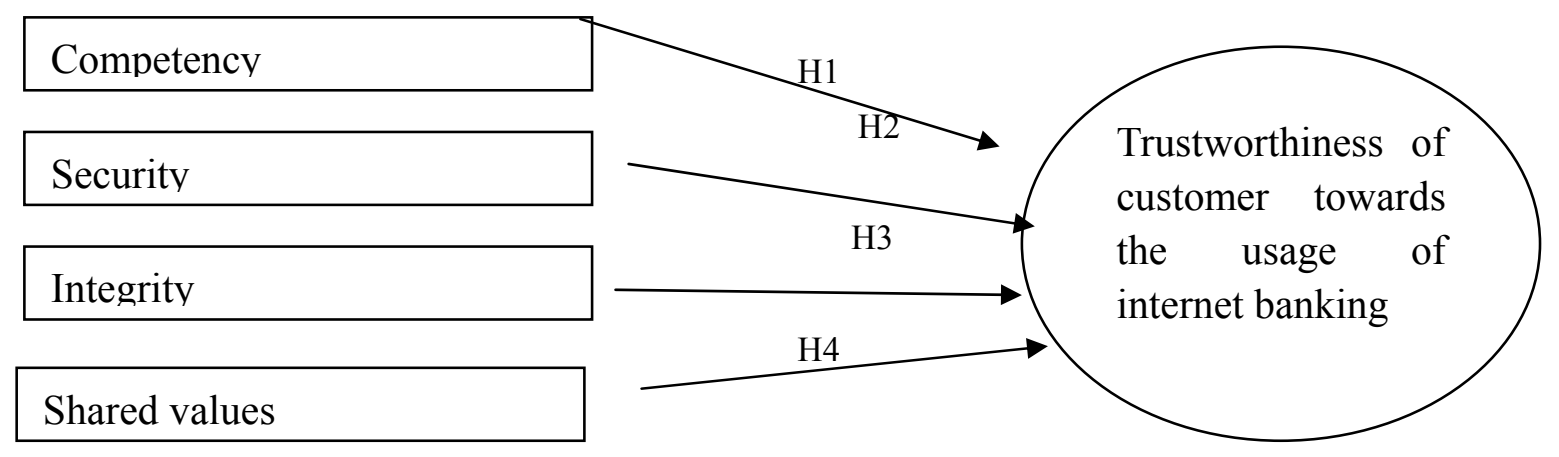




\section{Research Hypotheses}

H1: Competency will have a direct significant influence on trustworthiness of customer towards the usage of internet banking in Malaysia

H2: Security will have a direct significant influence on trustworthiness of customer towards the usage of internet banking in Malaysia

H3: Integrity will have a direct significant influence on trustworthiness of customer towards the usage of internet banking in Malaysia

H4: Shared value will have a direct significant influence on trustworthiness of customer towards the usage of internet banking in Malaysia

\section{Research Methodology}

\subsection{Measurement and Collection of Data}

A quantitative research approach is employed in this research following the positivist assumption with a realist ontology and objectivist epistemology. Data was collected using a probabilistic sampling method, particularly a stratified random sampling technique.

The adapted survey questionnaire employed in this study is divided into two sections; demography and scales of the four (5) underlying factors of the research instrument, capturing four (4) independent variables and 1 dependent variables. A 5-point Likert scale was used showing (1)"strongly disagree", (2) "disagree", (3) "slightly agree", (4) "agree", (5) "strongly agree". Table 1 below captures the details of the adapted scales employed in this research.

Table 1. Adapted scales from previous studies

\begin{tabular}{ll}
\hline Variable & Source \\
\hline 1) Competence & (Rogers, 2010) \\
2) Security & (Nasri, 2011) \\
3) Integrity Performance & (Ting, Kuen, Xien, Ying and Yew, 2013) \\
4) Shared Values & (Pay, Balaji and Kok, 2014) \\
\hline
\end{tabular}

\subsection{Demography of Respondents}

Table 2. Gender, Age, Race, Marital status and education level

\begin{tabular}{llll}
\hline Types & Categories & Frequency & Percent \\
\hline Gender & Male & 105 & 52.5 \\
Age & Female & 95 & 47.5 \\
& $18-24$ years old & 89 & 44.5 \\
& $25-31$ years old & 28 & 14.0 \\
& $32-38$ years old & 11 & 5.5 \\
Race & 39 years old and above & 36.0 \\
& Malay & 72 & 70.0 \\
& Chinese & 140 & 10.0 \\
Marital Status & Indian & 20 & 14.0 \\
& Others & 28 & 6.0 \\
& Single & 12 & 54.0 \\
Education Level & Married & 108 & 43.0 \\
& Divorced & 86 & 0.5 \\
& Widowed & 1 & 2.5 \\
& Foundation or Lower & 5 & 6.0 \\
& Diploma & 12 & 16.0 \\
& Bachelor Degree & 32 & 66.0 \\
\end{tabular}




\section{Data Analysis}

\subsection{Multiple Regression Analysis}

Multiple regression analysis is used to estimate the result and the risky forecasters (Pallant, 2016). Based on this study, it is determine by the relationship between the dependent and independent variables.

Table 3. Model summary

\begin{tabular}{|c|c|c|c|c|c|}
\hline \multicolumn{6}{|c|}{ Model Summary ${ }^{b}$} \\
\hline Model & $\mathrm{R}$ & R Square & Adjusted R Square & $\begin{array}{l}\text { Std. Error of the } \\
\text { Estimate }\end{array}$ & Durbin-Watson \\
\hline 1 & $.505^{\mathrm{a}}$ & .255 & .239 & .38477 & 1.816 \\
\hline
\end{tabular}

a. Predictors: (Constant), Shared Values, Integrity Performance, Security, Competency

b. Dependent Variable: Trustworthiness Of Internet Banking

\subsection{Model Summary}

According to the table 3, the Durbin-Watson value is used to determine errors from statistical analysis of auto correlation (Hoshmand, 2009). Referring back to the table above, the value of Durbin-Watson is 1.816. The value is ideal due to the value within 1 to 3 . Hence, the result outcome has no autocorrelation within the statistical analysis.

However, the value of the R Square is to determine the relationship between forecasters and the results. The value of $\mathrm{R}$ Square stated above is 0.255 which is $25.5 \%$. This shows that $25.5 \%$ of independent variable explains the different factors of the dependent variable. The remaining $74.5 \%$ are the factors that were not included in this study.

Table 4. ANOVAa

\begin{tabular}{lllllll}
\hline $\begin{array}{l}\text { ANOVA }^{\mathbf{a}} \\
\text { Model }\end{array}$ & & Sum of Squares & df & Mean Square & F & Sig. \\
\hline 1 & Regression & 9.865 & 4 & 2.466 & 16.659 & $.000^{\mathrm{b}}$ \\
& Residual & 28.869 & 195 & .148 & & \\
& Total & 38.734 & 199 & & & \\
\hline
\end{tabular}

a. Dependent Variable: Trustworthiness Of Internet Banking

b. Predictors: (Constant), Shared Values, Integrity Performance, Security, Competency.

Based on the table 4, the analysis of variance (ANOVA) is to measure the significance between two or more mean values. Based on the table above, the value of ANOVA is 0.00 which is lower than 0.05 . This states that this research is appropriate to use. All independent variables that were included in this research have been included. However, the ANOVA result does not represent total hypothesis that is significant.

Table 5. Coefficients ${ }^{\mathrm{a}}$

\begin{tabular}{|c|c|c|c|c|c|c|c|}
\hline \multicolumn{8}{|l|}{ Coefficients $^{\mathrm{a}}$} \\
\hline \multirow[b]{3}{*}{ Model } & \multirow{2}{*}{\multicolumn{2}{|c|}{ Unstandardized Coefficients }} & \multicolumn{5}{|c|}{ Standardized } \\
\hline & & & \multicolumn{3}{|c|}{ Coefficients } & \multicolumn{2}{|c|}{ Collinearity Statistics } \\
\hline & $\mathrm{B}$ & Std. Error & Beta & $\mathrm{t}$ & Sig. & Tolerance & VIF \\
\hline (Constant) & 2.134 & .275 & & 7.766 & .000 & & \\
\hline Competency & .115 & .052 & .161 & 2.213 & .028 & .720 & 1.390 \\
\hline Security & .267 & .060 & .315 & 4.450 & .000 & .763 & 1.311 \\
\hline IntegrityPerformance & .038 & .034 & .072 & 1.127 & .261 & .933 & 1.071 \\
\hline SharedValues & .109 & .060 & .147 & 1.814 & .071 & .586 & 1.707 \\
\hline
\end{tabular}

a. Dependent Variable: Trustworthiness of Internet Banking. 
Based on table 5, there are two variables which are greater than 0.05 which is integrity performance and shared values. Both variables that is greater than 0.05 is not significant. However, the value of competency and security is both lower than 0.05 which makes it significant. Based on this research, the hypothesis for competency and security are accepted while the hypothesis for integrity performance and shared values are rejected.

6.3 Hypotheses Result

\begin{tabular}{|c|c|c|c|c|}
\hline & Hypothesis & Sig & Result & $\begin{array}{l}\text { Gradient } \\
(\text { Beta, } \beta)\end{array}$ \\
\hline $\mathrm{H}_{1} 1$ & $\begin{array}{l}\text { There is a positive relationship between competency and the } \\
\text { trustworthiness of customers towards the usage of internet } \\
\text { banking in Malaysia }\end{array}$ & 0.028 & Supported & 0.161 \\
\hline $\mathrm{H}_{1} 2$ & $\begin{array}{l}\text { There is a positive relationship between security and the } \\
\text { trustworthiness of customers towards the usage on internet } \\
\text { banking in Malaysia }\end{array}$ & 0.000 & Supported & 0.315 \\
\hline $\mathrm{H}_{1} 3$ & $\begin{array}{l}\text { There is a positive relationship between integrity performance } \\
\text { and the trustworthiness of customers towards the usage on } \\
\text { internet banking in Malaysia }\end{array}$ & 0.261 & Not Supported & 0.072 \\
\hline $\mathrm{H}_{1} 4$ & $\begin{array}{l}\text { There is a positive relationship between shared values and the } \\
\text { trustworthiness of customers towards the usage on internet } \\
\text { banking in Malaysia }\end{array}$ & 0.071 & Not Supported & 0.147 \\
\hline
\end{tabular}

\section{Discussion of Findings}

\subsection{Result of the Correlation and Multiple Regression Analysis}

These results are from 200 respondents and all of the data are compute by SPSS. The reliability test has been gained by questions that were answered by the respondents. There are 2 different sections that divide the questions given. The first section is the demographic data of the respondents. The questions included are their gender, age, race, marital status and education level. The second section is 20 different questions regarding the independent variables which consist of competency, security, integrity performance and shared values. The pilot test was then derived from the first 20 respondents that were shown reliable and further continuity to the other 180 respondents was done after that. The reliability alpha score was 0.853 .

Then, the normality test was then done by using the Z-score calculation which the value was -1.465 lying within $-3<Z>3$. A curve graph in the histogram also showed normality based on the data collected. The linearity test described a normal distribution of the dependent and independent variables by using a scatter plot graph. Test was shown that the questionnaires were fairly distributed.

Next, the correlation test was tested by using Pearson correlation. The result that was tested was scored 0.322 for competency, 0.424 for security, 0.155 for integrity performance and 0.396 for shared values. Whereby competency, security and shared values has a low and moderate correlation and security has a very low correlation.

Finally, the multiple regression analysis is tested by using Durbin-Watson which the result was 1.816 and it indicated that there was no autocorrelation with the residual. Whereas, the R square result was $25.5 \%$ that shows the strength of the relationship between the dependent and independent variables. As for the ANOVA result, the significant value is 0.00 . There is two variables that was accepted and two variables which are rejected. The accepted variables are competency with 0.0028 and security with 0.000 significant values. The rejected variables are integrity performance with 0.261 and shared values with 0.071 significant values. There are some possibilities whereby the independent variables are not influenced by the dependent variable.

\subsection{Implication of the Study}

The outcomes of this research explores on the factors affecting the trustworthiness of customers towards the usage of internet banking in Malaysia. This research may be useful to the people in Malaysia as it increases the understanding on the factors related to the effects of trustworthiness towards internet banking.

With the technology advancement of today's century, the internet has become a major breakthrough of advanced technology. The buying and selling of products and services has become easier than before. Therefore, this research could help the people understand on why internet banking will make their lives simpler and easier. This 
research has the useful information on what factors that affects the trustworthiness of customers towards the usage of internet banking.

Internet banking could be a useful tool for the people and also businesses. By using this service, every transaction will be easier and there will not be any hassle regarding making any transactions especially big figures.

\subsection{Recommendation for the Future Research}

There are a few recommendations for future researchers to improve this topic on the trustworthiness of internet banking. First is the factors stated as independent variable could be further studied or even be added. This could widen the research on the topic.

Next is future researchers should widen the area of study. Questionnaires that are gained from different places may be more reliable than only in SEGi University staffs and students. Other than that, the knowledge of internet banking should be spread to everyone as it is one of the most convenient services as technology grows. With better information comes better understanding on internet banking.

\section{Conclusion}

The overall findings of the research that were done shows the reliability test results, normality test results, linearity test results, correlation test results and regression analysis test results. This chapter also includes the implication of the study, the limitations of the study and also the recommendations for future study.

The researcher believes that this research could be an important contribution for the people in Malaysia to broaden the understandings and the factors that affects trust in internet banking. The service provider of internet banking can also understand and identify the weaknesses of their service from this study. Trust is a main issue for this service, therefore this research will have an immense help to the service providers. Finally, this research will be a useful help for future researchers as there is lack of journals on the trust of internet banking in Malaysia. Even though this small research has no big impact, it is still consider as a small useful contribution for the better good of our society and nation.

\section{References}

Ackerman, M., Cranor, L., \& Reagle, J. (1999). Beyond concern: understanding Net users attitudes about online privacy. Working Paper, AT\&T Labs-Research. https://doi.org/10.1596/1813-9450-2308

Adler, P., \& Kwon, S. (2002). Social Capital; prospects for a new concept. Academy of Management Review, 17-19.

Alagheband, P. (2006). Adoption of e-Banking Services by Iranian Customers. unpublished Msc thesis. Lulea University of Technology, Division of Industrial Marketing and E-Commerce.

Aldridge, A., White, M., \& Forcht, K. (1997). Security Considerations of Doing Business Via Internet: cautions to be considered. Electronic Networking Applications and Policy, 9-15. https://doi.org/10.1108/10662249710159809

Al-Smadi, D. M. (2012). Factors Affecting Adoption of Electronic Banking: An Analysis of the Perspectives. International Journal of Business and Social Science.

Altman, E. (2000). Revisiting the Z-score and Zeta Models. Journal of Banking \& Finance, 1-54.

Bank Negara Malaysia. (2015). Bank Negara Malaysia. Retrieved 2016, from BNM: http://www.bnm.gov.my/?ch=ps\&pg=ps_regulatees

Bradley, L., \& Stewart, K. (2003). The diffusion of online banking. The Journal of Marketing Management, 87-109. https://doi.org/10.1080/0267257x.2003.9728252

Chen, L., Gillenson, M., \& Sherell, D. (2002). Enticing online consumers, an extended technology acceptance perspective. Information System Research, 5-19. https://doi.org/10.1016/s0378-7206(01)00127-6

Chuan, T. (2015). Bank Negara Malaysia. Retrieved 2016, from BNM: http://www.bnm.gov.my/documents/conference_vol/2015_PaymentSystem/1.\%20Outcomes\%20of\%20Reg ulatory\%20Measures\%200n\%20the\%20Payment\%20Landscape.pdf

Crosman, P. (2010). Online Banking Customers Expect Fast Website Performance, Survey Finds. Retrieved from Bank Systems and Technology: http://www.banktech.com/data-and-analytics/online-banking-customers-expect-fast-website-performance-s urvey-finds/d/d-id/1293506? 
Cunningham, J. (2003). The diffusion of Internet banking among Singapore consumers. International Journal of Bank Marketing.

Daniel, E. (1999). Provision of electronic banking in the UK and the Republic of Ireland. The International Journal of Bank Marketing, 72-82. https://doi.org/10.1108/02652329910258934

Giannakoudi, S. (1999). Internet banking: the digital voyage of banking and money in cyberspace. Information and Communications Technology Law, 43. https://doi.org/10.1080/13600834.1999.9965811

Hajli, N., \& Lin, X. (2014). Exploring the security of information sharing on social networking sites: The role of perceived control of information. Journal of Business Ethics.

Hernandez, J., \& Mazzon, A. (2007). Adoption of Internet banking: proposition and implementation of an integrated methodology approach. International Journal of Marketing.

Hoshmand, R. (2009). Business Forecasting Second Edition: A practical approach. Routledge.

Huemer, L. (1998). Trust in business relations: economic logic or social interaction?

Hutchinson, D., \& Warren, M. (2003). Security for Internet Banking: A framework. Logistics Information Management, 64-73. https://doi.org/10.1108/09576050310453750

Kassim, N., \& Abdulla, A. (2006). The influence of attraction on internet banking: An extension to the trust-relationship commitment model. International Journal of Bank Marketing, 42.

Lee, P. (2002). Behavioral Model of Online Purchasers in E-Commerce Environment. Electronic Commerce Reseacrh, 75-85. https://doi.org/10.1023/A:1013340118965

Levinson, M. (2009). The Economist: Guide to Financial Markets. John Wiley \& Sons .

Luarn, P., \& Lin, H. (2005). Toward an understanding of the behavioral intention to use mobile banking. Computer in Human Behaviour, 91. https://doi.org/10.1016/j.chb.2004.03.003

Minhas, R., \& Jacobs, E. (1996). Benefit Segmentation by Factor Analysis: an improved method of targeting customers for financial services. International Journal of Bank Marketing, 3-13. https://doi.org/10.1108/02652329610113126

Morgan, R., \& Hunt, S. (1994). The commitmet-trust theory of relationship marketing. Journal of Marketing, 20-38. https://doi.org/10.2307/1252308

Mukherjee, A., \& Nath, P. (2003). A model of trust in online relationship banking. International Journal of Bank Marketing, 5-15. https://doi.org/10.1108/02652320310457767

Mukherjee, A., \& Nath, P. (2007). Role of electronic trust in online retailing: a re-examination of the commitment-trust theory. European Journal of Marketing. https://doi.org/10.1108/03090560710773390

Nasri, W. (2011). Factors Influencing the Adoption of Internet Banking in Tunisia. International Journal of Business and Management, 6(8). https://doi.org/10.5539/ijbm.v6n8p143

Neeraj, M. (2015, February 13). E-stores must focus on milennials the most. Retrieved April 2016, from http://dazeinfo.com/2015/02/13/e-store-must-focus-millennials-80-smartphone-93-social-media-account-67 -buy-product-online/

Nilsson, M., Adams, A., \& Herd, S. (2005). Building Security and Trust in Online Banking. International Journal of Computing Systems. https://doi.org/10.1145/1056808.1057001

O'Sullivan, A., \& Steven, S. (2003). Economics: Principles in action. New Jersey : Pearson Practice Hall.

Pallant, J. (2016). SPSS Survival Manual: A step by step guide. Allen \& Unwin.

Pang, J. (1995). Banking and Finance in Malaysia. Federal Publications Sdn Bhd.

Pay, L. Y., Balaji, M., \& Kok, W. K. (2014). Building Trust in Internet Banking: A Trustworthiness Perspective. Journal of Industrial Management \& Data System, 7-8.

Paynter, J., \& Lim, J. (2001). Drivers and Impediments to E-commerce in Malaysia. Malaysian Journal of Library \& Information Science, 1-19.

Puschel, J., \& Mazzon, J. (2010). Mobile banking: Proposition of an intergrated adoption intention framework. International Journal of Bank Marketing. https://doi.org/10.1108/02652321011064908

Ratnasingham, P. (1999). Risks in low trust among trading partners in electronic commerce. Computers and Security, 87-92. https://doi.org/10.1016/s0167-4048(99)82005-7 
Rifon, N., LaRose, R., \& Choi, S. (2005). Your privacy is sealed: effects of web privacy seals on trust and personal disclosures. The Journal of Consumer Affairs, 62. https://doi.org/10.1111/j.1745-6606.2005.00018.x

Rogers, M. (2010). Consumers' Attitudes, Perceived Risk, Trust and Internet Banking Adoption in Uganda. Master's Thesis, Makerere University Business School, Uganda, 28-29.

Sabbagh, A., \& Molla, A. (2004). Adoption and use of Internet banking in the Sultanate of Oman: An exploratory study. Journal of Internet Banking and Commerce.

Sathye, M. (1999). Adoption of internet banking by Australian consumers: An empirical Investigation. International Journal of Bank Marketing, 322. https://doi.org/10.1108/02652329910305689

Sayar, C., \& Wolfe, S. (2007). Internet Banking Market. International Journal of Bank Marketing, 124. https://doi.org/10.1108/02652320710739841

Tan, M., \& Teo, T. (2000). Factors influencing the adoption of Internet Banking. Journal of the Association for Information System.

Ting, A., Kuen, F., Xien, G., Ying, L., \& Yew, W. (2013). Online Banking in Malaysia from Consumer Perception on Risk. Universiti Tunku Abdul Rahman, 33-35.

Verma, J. (2012). Data Analysis in Management with SPSS Software. Springer Science \& Business Media.

White, H., \& Nteli, F. (2004). Internet banking in the UK: why are there not more customers? Journal of Financial Services Marketing. https://doi.org/10.1057/palgrave.fsm.4770140

Wu, D., \& Wu, D. (2010). Performance Evaluation and Risk. Kybernetes, 723. https://doi.org/10.1108/03684921011043215

Yiu, C., Grant, K., \& Degar, D. (2007). Factors Affecting the Adoption of Internet. International Journal of Information Management, 330. https://doi.org/10.1016/j.jinfomgt.2007.03.002

\section{Copyrights}

Copyright for this article is retained by the author(s), with first publication rights granted to the journal.

This is an open-access article distributed under the terms and conditions of the Creative Commons Attribution license (http://creativecommons.org/licenses/by/4.0/). 